\title{
Environmental Health and Nursing: Implementation of Educational Workshops with Employees of General Services

\begin{abstract}
Paula Marciana Pinheiro de Oliveira', Maria Gleiciane Gomes Jorge ${ }^{2}$, Gisele Mendes da Silva², Edmara Chaves Costa1, Leilane Barbosa de Sousa1, Monaliza Ribeiro Mariano , Gilmara de Lucena Beserra ${ }^{3}$
\end{abstract}

\section{Abstract}

Background: to describe the contribution of educational workshops on environmental health for employees of general services at a public institution of higher education.

Method: exploratory, descriptive research with a qualitative approach. For the collection, a questionnaire with subjective and objective questions was used, and the steps of pretest, educational workshop and post-test wereincluded in March and April 2015, with 55 employees. For data analysis,thematic and categories were prepared.

Results: the themes consisted of the following: Interference of the environment where they live in their own health and the health of the family and community; Understanding of environmental health; Difficulty in maintaining the environment clean; and perception of the importance of hand hygiene.

Conclusion: people have fragmented knowledge about the concept of clean environment and its importance in maintaining health on Earth. It was clear that, after the educational workshops on the theme, there was improvement in the individuals' understanding on environmental health.
1 Nurse. Lecturer at theAfricanBrazilian Lusophone International Integration University (UNILAB), Redenção,Ceará, Brazil.

2 Academic of the nursing course at the African-Brazilian Lusophone International Integration University (UNILAB), Redenção,Ceará, Brazil.

3 Nurse. Master's Degree in Nursing by the Graduate Nursing Program at the African-Brazilian Lusophone International Integration University (UNILAB), Redenção,Ceará, Brazil.

Contact information:

Paula Marciana Pinheiro de Oliveira.

Address: African-Brazilian Lusophone International Integration University (UNILAB) Redenção, Ceará, Brazil.

\section{झ paulapinheiro@unilab.edu.br}

\section{Keywords}

Environmental Health; Nursing; Health Education. 


\section{Introduction}

The environmental impacts are increasingly present in the daily life of contemporary society. This can be seen by the means of communication daily reporting such information at the national and global levels. The main topics and issues discussed in the media are related to the pollution, deforestation, destruction of ecosystems and the consequent extinction of several species, fauna, flora and environmental disasters [1].

In this perspective, it is known the importance of preserving the environment and its relationship to health. Environmental risks have interconnection with health problems such as malnutrition and associated diseases; cardiovascular, respiratory, mental, dermatologic, infectious, cancerousdiseases. Furthermore, they can also contribute to the re-emergence of certain diseases caused by food contaminated with pesticides, water pollution, climate change, air pollution and destruction of ecosystems [2].

It is essential to think of (re)discussing the concept of environment, and including different perspectives associated with it (social, economic, cultural, among others) in order to get a look and action beyond the biomedical model. It is necessary to believe that, as health workers, they can and should make conscious decisions and act responsibly with the environment, because they are all social actors who respond by immediate and future actions. Therefore, it is essential to have a horizontal relationship between humans and the rest of the environment, as envisaged by Florence Nightingale, over a century ago [3].

Nursing plays an essential role in health education about the preservation of the environment for it has the highest number of professionals who provide health care in Brazil, specifically when working the health promotion theme. This area was inserted in the environment care with the Environmentalist Theory [4] because the environment affects the lives of people and can contribute to health or illness. Here, the environment is understood not only in a particular way, but as the workplace, residence, leisure site, among others.

In this context, nurses and other health workers should be effectively inserted in this area through actions that empower the individual and the community. Through these actions, they will show people the need for critical reflection to modify the behavior committed to environmental health. It is, then, the challenge of empowering people to accomplish activities considered environmentally friendly, since the economic, industrial and social developmentsare continuously stimulated and environmental degradation, more present.

As a professional, the nurse can act working issues about environmental health and its interference in human health. The educational activities on this subject should follow the axes of Health Promotion described in the Ottawa Charter, by expanding personal skills to strengthen community action in a collective articulation and, at the same time, to review the formulation of public policies to create healthy and pollution-free environments [5]. These environments, both residential as work, social, individual and collective, that is, where there are several people that, informed and with proper knowledge, can positively intervene.

This research aimed to analyze the contribution of educational workshops with professionals of general services on environmental health. This, since this public is still not involved in the theme, has wide importance for society by passing on globally. Also, there are few studies that work with the theme in question and this public.

\section{Method}

This is an exploratory, descriptive research, with a qualitative approach, conducted in a public institution of higher education located in the State of Ceará.

The research participants consisted of the staff of general services, since they deal directly with the care of the environment and the management of 
solid waste produced at the study site. The participants' selection criteria were: public or outsourced employee of general services over 18 years old and literate. The subjects who only completed the pretest were excluded from data analysis. In total, 55 employees participated in this study, being 64 the overall quantity of employees.

To perform the activities, classrooms located in the institutionwere reserved, air-conditioned, with minimal noise interference and preserving the group's privacy. The data were collected in March and April 2015. The activities were divided into two shifts according to the work schedule and availability of participants.

The research was implemented in three stages: the first one was the application of the pretest. In it, group interaction activities were also accomplished. To fill the pretest, the employees' prior knowledge about environmental health and the environment, ecosystems, municipal solid waste and health impacts, water contamination, environments (home, work and social) and acquired diseases in these contexts was identified. The use of personal protective equipment was also discussed. The development time for this stage was approximately one hour.

The second stage, in turn, was the realization of workshops focusing on issues addressed in the pretest. At this time, there were discussions on the subject with exposure of educational videos and images. Also, on the occasion, cutouts and collages from magazines were effectively implemented to show, with figures and phrases, the teachable moment. The duration of this stage was about an hour and a half.

In the third and final stage, the post-test was implemented, in order to identify the effectiveness of the acquired educational strategy in the workshop on the discussed information. At this time, there was also clarification on the subject.

The instrument used for data collection comprises two parts, in addition to identification, personal (age, sex, skin color, educational level, marital status, religion number of people in the residence, personal income) and professional profile of the participant. While the first part of the instrument addressed objective multiple-choice questions, the second part consisted of subjective questions related to the theme and its importance for each participant. In this work, it was decided to present the results of the qualitative approach (subjective questions), considered the last part of the instrument of pre- and post-test.

Importantly, there was a pilot test: after the preparation, the instrument was used by two employees of general services to assess the reading and interpretation of the questions.

For the data analysis, themes and categories were prepared, based on content analysis[6], discussed in the light of relevant scientific literature. Tables with the description of the subjects and categories and the number of descriptions of the participants fell into each were elaborated.

To participate in the study, the participants filled out and signed the Informed Consent Form confirming knowledge about benefits and possible risks of the study. As proposed, the study complied with Resolution 466/2012, inherent to respect, individuality, privacy and right of the search withdrawal at any time, if desired. It was approved by the Research Ethics Committee with protocol number 962.995.

To ensure privacy, the speeches of the subjects were identified with the letter " $F$ " (employee - funcionárioin Portuguese)followed by cardinal numbers, identifying them, "F1", "F2", "F3", etc.

\section{Results}

The participants were 55 employees of general services, aged between 19 and 49 years,mostly women (58.18\%). Most of them attended high school (50.91\%), were married/in stable union (52.73\%) and have a family income from one to three minimum wages (58.18\%).

The main results emerged issuesconcerning the knowledge of the pre-test such as the interference of the environment where they live in their own 
health and the health of the family and community; Understanding of environmental health; Difficulty in maintaining the environment clean; and perception of the importance of hand hygiene. The two first issues remained in the post-test. For each theme, there were categories according to the organization of the findings and the number of subjects who reported such response.

Interestingly, regarding the first theme, the categorization the environment does not help in health and theenvironmenthelpsin health, participants understand the link between environment and health, and recognize this interdependence, and say that the environment does not help in health, as it is vandalized and poorly maintained, just by the established anthropocentric relationship. So it is not that the environment does not contribute to health, but as participants listed in its current inappropriate state (pollution, waste without sanitation), there really is no way to contribute.

Indeed, the categories have the same reasoning described in a dichotomized way: one depicts the unhealthy environment and its negative relation to health; the other describes the cleanenvironment, without pollution, and its connection with the healthy.

Next, the Tables 1 and $\mathbf{2}$ are exposed with the themes, categories and number of participants in each.

Table 1. Presentation of the themes and categories related to the questions and answers of the pre-test.

\section{Pre-test themes}

Interference of the environment where they live in their own health and in the family's and community's health

Comprehension about environment health

Difficulty in maintaining the environment clean

\section{Pre-test categories}

The environment doesn't help in health $(n=37)$

The environment helps in health $(n=15)$

Cleaning and preservation of the environment $(n=36)$

Environment awareness/ knowledge $(n=31)$

No difficulty $(n=15)$

Lack of materials $(n=7)$
Table 2. Presentation of the themes and categories related to questions and answers of the post-test.

\section{Post-testthemes}

Post-testcategories

Interference of the environment The environment doesn't where they live in their own help in health $(n=35)$

health and in the family's and community's health The environment helps in health $(n=16)$

Comprehension about environment health

Cleaning and preservation of the environment $(n=47)$

\section{$1^{\text {st }}$ Theme: Interference of the} environment where they live in their own health and the family's and community's health

that there is pollution, and, to change this situation, people should be aware. Some individuals, however, both in the pre (15) as in the post-test (16), answered, in turn, that the environment does help in health. In this theme, there were two categories: the environment doesn't help in health and the environment helps in health.

In this first category, the environment does not help inhealth, the participants showed knowledge and responded in a complementary manner to one another. These descriptions below are the answers regarding the pretest:

No. Because I think there is still a lot of dirt around us, trash, open sewer, with no sewerage, blown cavities and poor quality of water we drink.

It does not help, we live in a completely polluted environment; the pollution mainly caused by man has been gradually taking our health, leaving we sick and hurting us.

No, because various providences have to be taken, such as: particularly the part that applies to education, awareness of the correct way. Ex: health heavily depends on hygiene and vice versa. 
No, because today the environment is full of poIlution as bags, pigs and many cats doing their needs in the street, etc.

They (people) are the first to pollute the streets

In the post-test, in turn, there was not much difference in the responses, although the descriptions were more summarized:

It doesn't help, the human beings need to gain conscious.

No, there's a lot of pollution in the air, rivers and has many open sewers.

No, because we depend on each other and not all neighbors are united.

No, because we do not have basic sanitation, and people also do not do their roles in keeping our city clean.

In the second category, as the descriptions evidenced, the environment helps in health,the number of subjects who described this way was considerable (15). They indicated, in general, the environment where they live, as most live in mountains, where the weather is cold and the air is pure. They also mentioned the importance of environmental awareness and individual action as an essential part for environmental health. The descriptions of the pretest:

Yes, just calmly walking in the air is already much of a thing.
Yes, for it's clean.

Yes, if I help clean it.

Yes. Because we have potable water, we live in an environment where the litter is collected.

Yes. Because some people are learning how to take care of it and, where I live, the neighbors are very careful with their litter and with the cleaning itself.

Yes, llive in a goodplace.

In the posttest, the descriptions were similar, as can be observed:

I think so because I live on a hill and there is less pollution and less dirt.

Yes, because the street where I live people are careful with cleaning.

Yes, clean environment, guaranteed health.

Yes. If we help to clean up our city not throwing garbage or producing fires, we are already collaborating on health.

\section{$2^{\text {nd }}$ Theme: Understanding of environmental health}

The second theme asked what the individual meant by environmental health. In both pre (36) as the post-test (47), the majority responded about conservation and health of the environment. Then, the 
following category arose: Cleaning and conservation of the environment.

In this, the subjects mentioned (in their own perspective) the ideal way for maintenance and preservation of the environment. The following statements are related to the pre-test responses:

I understand that, for us to have good health, we should be more careful with our environment, our planet. We, humans, often pollute the environments.

Environmental health is everything related to cleanliness, nature and environment.

I understand that we must first preserve the environment around us. We have to be more careful with anything that might contaminate us not to cause disease.

We should contribute with several factors, not polluting rivers and nor the sea, ponds and lakes.

In my opinion, it's every one of us having our own conscience and keeping the environment where we live and attendalways clean.

It's the knowledge to keep our environment always clean, starting at our homes and also at our work.

F26.

In the posttest, the descriptions were similar. As evidenced, the participants answered with knowledge of the subject. The most complete answers, in which stood out the most scientific language and the aggregate knowledge, were the following:
It's all that is related to how to properly dispose of garbage and behave in society, with a clear conscience and knowledge of recycling.

I understand that, if we have consciousness, do garbage collection and recycling, it will be better for our environmental health.

No littering, always keeping the environment clean.

Environmental health is living in harmony with nature, speaking to a better future without garbage in the streets and sidewalks, taking care of our water and ourselves.

According to these statements in these themes and categories, knowledge of the subjects in the pre and post-test could be improved, and the description of this evolution, seeking more correct and formal language, was noticeable.

Continuing the research findings, for the preparation of the post-test instrument, one question was deleted in relation to the pre-test: "What is your greatest difficulty in promoting a clean environment?". Since it had already been completed in the pre-test and had no interference with the educational workshops.

\section{$3^{\text {rd }}$ Theme: Difficulty in maintaining the environment clean}

The third theme is related to the question about the difficulty in promoting a clean environment. Like most of the answers showed (31), there is concern with the awareness of society. In this theme, there was a category: Environmental Awareness/ Knowledge.

The following descriptions represent it: 
For me, the biggest difficulty inleaving a clean environment is that people do not help to leave their homes and other environments clean, they don't do it how it should be done.

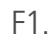

People do not know that trash is in trash. They put it anywhere.

It's in the lack of information and guidance.

People need to use kindness and awareness for themselves and the humanity.

The biggest one is saying the other doesn't do anything to keep the environment clean. First of all, I have to play my part and not charge from the other.

It should be noticed: according to the some responses of the research subjects, they found no difficulties to maintain the environment clean. This may be related to a few activities implemented by this subject in the workplace at the time the data were being collected, since it is place still little used because of recent buildings, new campus.

\section{Discussion}

The first thematic pointed the interference of the environmental in health. To underscore the interposition of the environment on health is essential, since itsconditions and preservation are important for health and disease process. As stated in this theme, most of the subjects, both before as after the educational workshop, describes that the environment does not help in their health. In fact, there is no contradiction between the opinions, as polluted environments do not help in health; but the experience with salubrious environments takes participants to conclude so. In both categories, it can be evidenced consistency in the responses and agreement on the interrelationship environment/ health, even in a dichotomized way. Participants mention the issue of pollution ingeneral: the environment, work, home and leisure.

The pollution affects the population at all levels. Polluting the environment means causing damage to the soil, air and water. This negatively impact on the health with the depletion of natural resources, the advance of poverty, the imbalance of ecosystems, diseases caused by contaminated food, water and air [7]. Dissatisfaction with the scenario experienced by the subjects reflected in the lack of maintenance of healthy and clean spaces, preservation of natural environments, production and consumption of healthy food, proper disposal of waste, recycling, among others. Thus, society becomes vulnerable to diseases. This issue is included not only in underdeveloped countries, but also in developed ones, forming a global concern in several areas.

Still in this context, the notes made by the individuals show environmental awareness as a key factor. Environmental responsibility is necessary for accomplishing changes in individual, collective and political behavior in the search for better environmental conditions and quality of life of human beings. For this, educational activities must relate knowledge to practice, to stimulate critical reflection, creativity and sensitivity to health promotion.

These educational practices seek to solve environmental problems through dialogue, guidelines, reciprocal information, providing conditions for social actors, possibilities to add concepts to implement the initiatives in environmental preservation actions [8].

In the second theme, it was observed that the subjects understand about environmental health. The majority associated cleaning with the preservation of the environment. In this sense, the indirectly characterized the concept of environmental 
health as the relationship between human health and nature, interdependently, where the change of space is adopted as a determinant of environmental health, and environmental issues are presented as risks to quality of human life [9]. So, keeping and preserving the environment clean contributes to environmental and human health.

With the most comprehensive look about the concept, understanding of the environment in disease prevention actions and health problems in people's experience is noticeable. In addition, in the post-test, more knowledgewas added, and the importance of preserving the environment wasemphasized, as well as the proper disposal of waste, selective collection and recycling. Specifically for employees of general services, these are elements integrated to actions on the environment, as they offer active and effective participation, assuming the role of lead actor in the pursuit of preserving a health beneficial environment [10].

According to a study, the health professionals still perceive environmental issues as segregation of materials; they denote concern about the lack of educational activities and care with the community, and the lack of government investment to work this theme [11]. Regarding ecological care for health students and professors, it is necessary to train educators about awareness, teaching methodologies for the development of environmental awareness of students [12]. In this study, it was chosen to work with employees in general services, seeking ecological awareness and the importance of this matter nowadays.

That same study pointed out, in educational workshops, that subjects extended their concept about the meaning of environmental health and improved their knowledge about the relationship between health and environment, in order to improve the professional practice of the staff. In the construction of the proposed materials for the workshops, it was observed the maturity of the subjects on the theme.
In this light, the acquired knowledge sought help to better implement the work and the sharing of future learning in the family. Therefore, it could not only transform themselves and their surroundings, but also present results as an intellectual and professional growth by modifying the environment where they live, because they live in a society in which attitudes can influence both positively and negatively [13].

In the third theme, it was observed that the awareness of clean environment is necessary, and its theory and practice relationship needs to arise from each individual, in changing habits, with a view to environmental education in the political, economic, social and cultural spheres. Since it is a gradual process, it is essential ongoing education and involvement. Interactive, mutual and dynamic habits are required from individuals in all dimensions, considering the evolution of knowledge and proper respect for the environment.

Within the environmental aspects, inadequate routine actions of individuals have highly detrimental effect, especially because people prefer not to view the situation. For them, it is more comfortable to act in a reckless manner than take responsibility for their actions and put into practice actions that could uniquely be carried out and that would result in the common and collectivewelfare [14].

During the educational workshops, an interactive activity about hand hygiene was performed. An employeeparticipated in the moment and interacted with others in the pursuit of learning. Next, the appropriate form of the procedure was demonstrated, considered essential for health in disease prevention and combating the spread of infection. Health professionals should work with this theme to raise awareness of all, for society generally handles food and materials which requires clean hands. In the case of this study, and certainly in many institutions and companies, general services professional needed and need these clarifications. This will help in cleaning and personal and professional growth. 
In this sense, it is up to nurses and other health workers to guide and raise awareness about the care of the planet. Their task is to educate and empower the society to actively participate in the preservation of the environment and maintaining a sustainable universe. As nursesare directly linked to the care of the human being and the quality of life in the maintenance and promotion of health, and also in contributing to the improvement of environment through educational practices and awareness of environmental issues, they should work this issue [15]. Therefore, they will play an essential role in society, in the constant pursuit of environmental stability and understanding of performances in health promotion, reflecting the issues of ecological imbalance and its link to health problems.

As a care professional, the nurse has a duty to provide expansion of knowledge and actions in the context of his/her activities, improving the search for environmental welfare in society, directly and positively contributing for the lives of human beings [16].

\section{Conclusions}

In this study, the general service employees have relative awareness of the concept of clean environment and its importance for maintaining health on Earth. As noticed, after the educational workshops, regarding the themes related to the understanding of the individuals of environmental health, the number of responses and the way of expression of the subjects improved and expanded in terms of ideas, translating the knowledge gained in the activities. It is essential to pursue an individual health and care for their environment, knowing that it can interfere with the health of the world.

After the educational workshops in all proposed topics and categories, there were more complete responses working the individual and the world environment. This is essential because the awareness that an individual action may lead to greater con- sequences, leading the individual to think and act today and in the future in a positive way.

The challenges are intense. Acting ecologically, consciously and in a responsible manner, taking into account that, in most cases, subsidies required for this ecological practice are not available, is difficult. Given the impasse, it takes dedication and support of general practitioners, after all, the environment interferes in an inter-sectorial manner, that is, in the most diverse sectors, in health.

As a professional who is also an educator and promoter of health, the nurse must work the importance of this issue for he/she has the knowledge of the impact of environmental issues on health in a mediate and immediate way. Although this is an area of high importance, this theme is little explored. So, educational measures are essential to promote the empowerment of people focused on social and environmental responsibility with a view to sustainability. Therefore, further studies should be made in this area in view of expansion and awareness.

It is noteworthy: the research was limited to general service staff of a university environment in which there is production of knowledge, including environmental health and sustainability. Therefore, it is suggested the development of more studies with employees who handle solid waste in other areas, such as hospitals, schools and shops, in order to ascertain whether the practice of these professionals is influenced by the working environment policy.

\section{References}

1. Soares SGA, Camponogara S, Terra MG, Santos TM, Trevisan CM. O que pensam os enfermeiros sobre a problemática ambiental. Rev Rene. 2012; 13(5):971-82. Disponível em: http:// www.redalyc.org/articulo.oa?id=324027984002

2. Lopes MSV, Ximenes LB. Enfermagem e saúde ambiental: possibilidades de atuação para a promoção da saúde. RevBrasEnferm. 2012; 64(1):72-7. Disponível em: http://dx.doi. org/10.1590/S0034-71672011000100011 
3. Camponogara S. Saúde e meio ambiente na contemporaneidade: o necessário resgate do legado de Florence Nightingale. Esc Anna Nery. 2012; 1(16):178-84. Disponível em: http://dx.doi. org/10.1590/S1414-81452012000100024

4. Haddad VCN, Santos TCF. A teoria ambientalista de Florence Nightingale no ensino da escola de enfermagem Anna Nery (1962-1968). Esc Anna Nery. 2011; 15(4):755-61. Disponível em: http://dx.doi.org/10.1590/S1414-81452011000400014

5. Beserra EP, Alves MDS, Pinheiro PNC, Vieira NFC. Educação ambiental e enfermagem: uma integração necessária. Rev Bras Enferm. 2010; 63(5):848-52. Disponível em: http://dx.doi. org/10.1590/S0034-71672010000500026

6. Bardin L. Análise de conteúdo. Lisboa (PT): Edições 70; 2011.

7. Porto MF, Finamore R. Riscos, saúde e justiça ambiental: o protagonismo das populações atingidas na produção de conhecimento. Ciênc Saúde Coletiva. 2012; 17(6):1493-501.

8. Camponogara S, Viero CM, Erthal G, Rossato GC. Enfermagem e meio ambiente: uma revisão bibliográfica. Enferm UFSM. 2011; 1(3):472-80. Disponível em: http://dx.doi. org/10.5902/217976923268

9. Ramos RR. Saúde ambiental: uma proposta interdisciplinar. Hygeia. 2013; 9(16):67-73. Disponível em: http://www.seer.ufu. br/index.php/hygeia/article/view/21027

10. Pelegrini AHW, Cezar-Vaz MR. Atenção primária ambiental no trabalho das enfermeiras da rede básica de saúde- estudo de corte transversal. Online Braz J Nurs. [periódico na Internet]. 2010 [citado 2014 ago. 21]; 9(1): [cerca de 9 p]. Disponível em: http://www.objnursing.uff.br/index.php/nursing/article/ view/j.1676-4285.2010.2851/638

11. Peres RR, CamponogaraS, Silva AC, Jacobi EO, Bataglin MS, Soares SGA. A responsabilidade ambiental sob a ótica de trabalhadores da atenção básica à saúde. R Pesq Cuid Fundam Online. [periódico na Internet] 2013 [citado 2014 ago. 21]; 6(3):1090-4. Disponível em: http://pesquisa.bvs.br/brasil/ resource/pt/bde-25647

12. Koerich MS, Backes DS, Drago LC, Bckes MS, Erdmann AL. O significado do cuidado ecológico para estudantes e professores da área da saúde: estudo qualitativo. Online Braz J Nurs. [periódico na Internet]. 2010 [citado 2014 ago. 21]; 9(1):2030. Disponível em: http://www.objnursing.uff.br/index.php/ nursing/article/view/j.1676-4285.2010.2781/622

13. VieroCM, CamponogaraS, SariV, Erthal G. Percepção de docentes enfermeiros sobre a problemática ambiental: subsídios para a formação profissional em enfermagem. Texto Contexto Enferm. 2012; 21(4):757-65. Disponível em: http://dx.doi. org/10.1590/S0104-07072012000400005

14. Baggio MA, Callegaro GD, Erdmann AL. Significando o cuidado ecológico/planetário/coletivo/do ambiente à luz do pensamento completo. Rev Min Enferm. 2011; 15(1):11-8. Disponível em: http://saudepublica.bvs.br/pesquisa/resource/pt/bde-20300
15. Freitas LV, Joventino ES, Ximenes LB, Vieira NFC, Moreira RVO. A ética do cuidado de enfermagem diante da crise ambiental. Online Braz J Nurs. [periódico na Internet]. 2012 [citado 2014 ago. 21]; 11(3):893-06. Disponível em: http://www.objnursing. uff.br/index.php/nursing/article/view/3833/html 1http:// www.objnursing.uff.br/index.php/nursing/article/view/3833/ html 2http://www.objnursing.uff.br/index.php/nursing/article/ view/3833/html

16. Beserra EP, Alves MDS, Rigotto MR. Percepção de adolescentes acerca da saúde ambiental: pesquisa-ação no espaço escolar. Online Braz J Nurs. [periódico na Internet] 2010 [citado 2014 ago. 21]; 9(1) [cerca de 9 p]. Disponível em: http://www.objnursing.uff. br/index.php/nursing/article/view/j.1676-4285.2010.2740/603
Publish in International Archives of Medicine

International Archives of Medicine is an open access journal publishing articles encompassing all aspects of medical science and clinical practice. IAM is considered a megajournal with independent sections on all areas of medicine. IAM is a really international journal with authors and board members from all around the world. The journal is widely indexed and classified Q1 in category Medicine. 